\title{
横方向プレストレスを導入した高強度コンクリート柱のせん断挙動に及ぼす 能動的拘束効果

\author{
EFFECT OF ACTIVE CONFINEMENT ON SHEAR BEHAVIOR \\ FOR HIGH-STRENGTH CONCRETE COLUMNS PRESTRESSED LATERALLY
}

\author{
篠原保二*，朴 世万**，大家 史***，渡部 洋**** \\ Yasuji SHINOHARA, Seiman BOKU, Fumito OHYA \\ and Hiroshi WATANABE
}

\begin{abstract}
Experiments and 3-D FEM analyses were performed on high-strength concrete columns laterally prestressed by the shear reinforcements to study the influence of the active confinement upon shear strength and crack behaviors. The lateral prestress has been introduced in proportion to the strength of concrete, and the width of every crack over transverse reinforcements has been measured by a microscope. By increasing the lateral pressure as mentioned above, shear crack strength and ultimate shear strength have increased proportionally, however, the effectiveness of active confinement has been weakened with decreasing axial force ratio. The FEM analyses can evaluate the shear crack strength and ultimate shear strength, and explain the effect of the active confinement on shear behaviors by evaluating the intensity of confinement in tri-axial state of stress with minor principal stress and equivalent confining pressure.
\end{abstract}

Keywords: High-strength concrete, Lateral prestress, Active confinement, Shear behavior, 3-D finite element analysis, Shear damage evaluation 高強度コンクリート, 横方向プレストレス, 能動的拘束, せん断挙動, 三次元有限要素解析, せん断損傷評価

\section{1. はじめに}

鉄筋コンクリート（以下 RC と略記）柱の耐震性，耐久性，修復 性を向上させるために，せん断補強筋に高強度鉄筋を使用し，その 補強筋に緊張力を加えて横方向のプレストレスを導入した RC 柱試 験体の曲げせん断実験を行ってきた ${ }^{1)-4)}$ 。さらに三次元有限要素解 析を行い, せん断ひび割れ耐力の上昇, せん断終局耐力の上昇, せ ん断ひび割れ幅の低減 (特に残留ひび割れ幅), 付着割裂耐力の上昇 など横方向プレストレスによる能動的拘束が RC 柱のせん断挙動に 与える効果をコアコンクリートの三軸応力状態に基づいて明らかに してきた。

近年フリープランのニーズによる柱間の長スパン化，高層化に伴 う下層階柱の長期鉛直荷重増大及び地震時の高せん断応力負担など によって, 鉄筋コンクリート造建物における高強度材料の使用は必 要不可欠であり, 今後も更なる高強度化が進むと考えられる。そこ で本報では, 横方向プレストレスを導入した高強度コンクリートRC 柱の曲げせん断実験を行い，能動的拘束が高強度コンクリート柱の せん断挙動に与える効果について考察する。使用するコンクリート 強度は前報 $\left(45 \mathrm{~N} / \mathrm{mm}^{2}\right)$ までの 2 倍の $90 \mathrm{~N} / \mathrm{mm}^{2}$ とし, 遒入する横方 向プレストレス量もコンクリート強度に比例して 2 倍とする。ただ
し試験装置の関係で軸力比を前報 (0.30)の半分の 0.15 とするため, 軸力比が能動的拘束効果に与える影響についても考察する。曲げせ ん断実験では，主にせん断ひび割れ性状に及ぼす横方向プレストレ スの影響を明らかにすることを目的として，横補強筋に複数枚のひ ずみゲージを貼付し，横補強筋上の全てのせん断ひび割れ幅をデジ タルマイクロスコープで計測している。また, 三次元有限要素解析 では，横方向プレストレスの導入による能動的拘束効果に及ぼすコ ンクリート強度および軸力比の影響を内部応力状態に基づいて検討 することを目的としている。なお，本報は文献 5),6)を統合し，修正・ 加箻したものである。

\section{2. 実験および解析概要}

\section{1 対象試験体と要素分割}

Fig. 1 に試験体詳細およびその解析要素分割を, Table 1 に試験体 諸元を示す。今回採用した試験体は，目標とするコンクリート強度 を 45 と $90 \mathrm{~N} / \mathrm{mm}^{2}$ (以下 Fc45 と Fc90 と略記) の 2 種類とし, 横方 向プレストレスを導入しない $\mathrm{RC}$ 試験体と導入した LPRC 試験体の 計 4 体である。前報 ${ }^{3)}$ の軸力比 0.3 の試験体 2 体についても比較検討 の対象とする。試験体形状は前報 ${ }^{3)}$ と同じであり，断面が $340 \times 340$
* 束京工藕大学建筑物理研究センター 助教授・工博

** 粦アイ・テック 工修

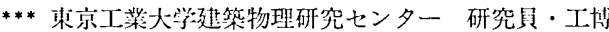

****主崎総合科学:大学建筑学:科講師・工博
Assoc. Prof., Struct. Eng. Research Center, Tokyo Institute of Technology, Dr. Eng. ITEC Corporation, M. Eng.

Research Fellow, Struct. Eng. Research Center, Tokyo Institute of Tech., Dr. Eng. Assist. Prof., Dept. of Architecture, Nagasaki Institute of Applied Science, Dr. Eng. 
$\mathrm{mm}$, せん断スパン比が 1.3 である。LPRC 試験体はコンクリート強 度 $\sigma_{B}$ に比例した横方向プレストレス量 $\sigma_{L}\left(=p_{w} \sigma_{w p}\right)$ を導入し（前 報 ${ }^{3)}$ と同じ $\left.\sigma_{L} / \sigma_{B} \approx 0.03\right), \mathrm{RC}$ 試験体をせん断破壊先行型の破壊モ 一ドとなるよう勒性指針 7)を参考に計画した。全試験体とも補強筋 として，高強度の溶接閉鎖角型せん断補強筋（便宜上横補強筋と呼 称する）を使用し，さらに普通強度の付着割裂防止筋（D13）を横 補強筋と同じ間隔で配している。Fc90 でコンクリート強度に比例し た横方向プレストレスを導入する場合，Fc45 と同じ横補強筋 U6.4 $\left(\mathrm{As}=30 \mathrm{~mm}^{2}\right)$ を使用するとプレテンションが降伏強度の $80 \%$ 程度 となり，プレテンション導入時に破断する恐れがある。そこで Fc 90 試験体については，横補強筋として U9.0（As=64 mm²）を使用し， U6.4 との組み合わせについては5 章の解析によって検討することと した。試験体名はプレストレスの有無（LPRC と RC），目標コンク リート強度の数值 $(45$ と 90$)$ およよ゙軸力比 $(0.15$ と 0.30$)$ によって 表す。使用したコンクリートの調合を Table 2 に示す。Fc45 は前報 と同様に早強ポルトランドセメントを Fc90 にはシリカフュームセ メントを使用し，両調合とも高性能 $\mathrm{AE}$ 減水剂を添加している。コ

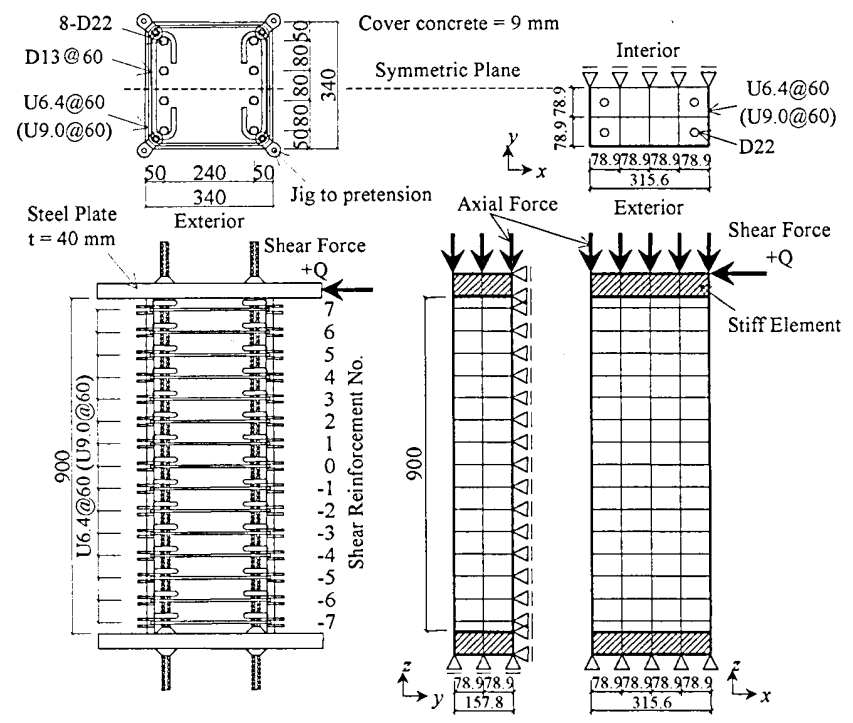

Fig. 1 Details of test specimen and finite element model (unit: $\mathrm{mm}$ )

Table 1 List of test specimens

\begin{tabular}{|c|c|c|c|c|c|c|}
\hline $\begin{array}{c}\text { Test } \\
\text { Designation }\end{array}$ & $\begin{array}{c}\sigma_{B} \\
\left(\mathrm{~N} / \mathrm{mm}^{2}\right)\end{array}$ & $\sigma_{0} / \sigma_{B}$ & $\begin{array}{c}p_{w} \\
(\%)\end{array}$ & $\begin{array}{c}\sigma_{w p} \\
\left(\mathrm{~N} / \mathrm{mm}^{2}\right)\end{array}$ & $\begin{array}{c}\sigma_{L} \\
\left(\mathrm{~N} / \mathrm{mm}^{2}\right)\end{array}$ & $\sigma_{L} / \sigma_{B}$ \\
\hline RC-45-0.15 & 44.2 & \multirow{2}{*}{0.15} & 0.29 & 0 & 0 & 0 \\
\cline { 1 - 4 } \cline { 5 - 7 } LPRC-45-0.15 & 46.2 & & 513 & 1.5 & 0.032 \\
\hline RC-90-0.15 & 91.9 & \multirow{2}{*}{0.15} & \multirow{2}{*}{0.63} & 0 & 0 & 0 \\
\hline LPRC-90-0.15 & 93.0 & & & 428 & 2.7 & 0.029 \\
\hline RC-45-0.30 & 50.8 & \multirow{2}{*}{0.30} & \multirow{2}{*}{0.29} & 0 & 0 & 0 \\
\cline { 1 - 4 } \cline { 5 - 7 } LPRC-45-0.30 & 46.5 & & & 536 & 1.6 & 0.034 \\
\hline
\end{tabular}

$\sigma_{B}=$ compressive strength of concrete, $\sigma_{0}=$ axial stress of column, $p_{\mathrm{w}}=$ ratio of transverse hoop, $\sigma_{\mathrm{wp}}=$ introduced prestress in transverse hoop, $\sigma_{L}=$ lateral prestress $\left(=p_{w} \sigma_{w p}\right), \mathrm{RC}-45-0.30$ and LPRC-45-0.30 from Ref. (3)

Table 2 Mix proportion (Unit: $\mathrm{kg} / \mathrm{m}^{3}$ )

\begin{tabular}{|c|c|c|c|c|c|c|}
\hline $\begin{array}{c}\text { Nominal } \\
\text { Strength }\end{array}$ & W/C & Water & Cement & Sand & Aggregate & $\begin{array}{c}\text { Super- } \\
\text { plasticizer }\end{array}$ \\
\hline Fc45 & 0.50 & 184 & 373 & 762 & 945 & 0.93 \\
\hline Fc90 & 0.30 & 155 & 517 & 857 & 861 & 3.88 \\
\hline
\end{tabular}

ンクリートの練り混ぜでは，ミキサー容量の都合上 2 回に分け， 2 バッチ分を良く混ぜ合わせたものを試験体に縦打ちした。Fc45 の空 気量は $2.1 \%$ ，スランプは $21.5 \mathrm{~cm}, F \mathrm{Fc} 90$ の空気量は $1.1 \%$, スラン プフローは $52 \mathrm{~cm}$ であった。コンクリートおよび鉄筋の材料特性を Fig. 2 および Fig. 3 に，解析におけるモデル化と合わせて示す。
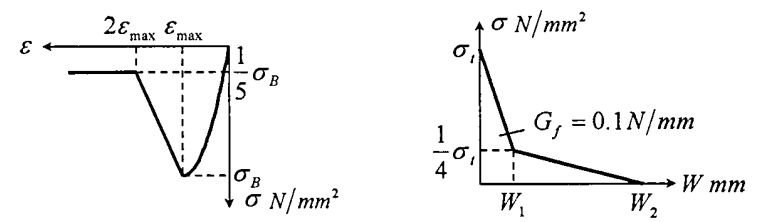

Compressive stress-strain curve Tensile stress-crack width curve

\begin{tabular}{|c|c|c|c|c|c|c|c|}
\hline $\begin{array}{c}\text { Test } \\
\text { series }\end{array}$ & $\begin{array}{c}\sigma_{\mathrm{B}} \\
\mathrm{N} / \mathrm{mm}^{2}\end{array}$ & $\varepsilon_{\max }$ & $\begin{array}{c}\mathrm{E}_{\mathrm{c}} \\
\mathrm{N} / \mathrm{mm}^{2}\end{array}$ & $\begin{array}{c}\sigma_{\mathrm{t}} \\
\mathrm{N} / \mathrm{mm}^{2}\end{array}$ & $\begin{array}{c}\mathrm{W}_{1} \\
\mathrm{~mm}\end{array}$ & $\begin{array}{c}\mathrm{W}_{2} \\
\mathrm{~mm}\end{array}$ & $v$ \\
\hline RC-45-0.15 & 44.2 & -0.002 & $3.34 \mathrm{E}+4$ & 2.6 & 0.034 & 0.17 & 0.2 \\
\hline LPRC-45-0.15 & 46.2 & -0.002 & $3.41 \mathrm{E}+4$ & 2.7 & 0.033 & 0.16 & 0.2 \\
\hline RC-90-0.15 & 91.9 & -0.0026 & $4.21 \mathrm{E}+4$ & 5.3 & 0.017 & 0.083 & 0.2 \\
\hline LPRC-90-0.15 & 93.0 & -0.0026 & $4.30 \mathrm{E}+4$ & 5.3 & 0.017 & 0.083 & 0.2 \\
\hline RC-45-0.30 & 50.8 & -0.002 & $3.51 \mathrm{E}+4$ & 2.9 & 0.031 & 0.15 & 0.2 \\
\hline LPRC-45-0.30 & 46.5 & -0.002 & $3.45 \mathrm{E}+4$ & 2.9 & 0.031 & 0.15 & 0.2 \\
\hline
\end{tabular}

Fig. 2 Mechanical properties and analytical model for concrete

\begin{tabular}{|c|c|c|c|}
\hline Type & $\begin{array}{c}\sigma_{y} \\
\left(\mathrm{~N} / \mathrm{mm}^{2}\right)\end{array}$ & $\begin{array}{c}\sigma_{\max } \\
\left(\mathrm{N} / \mathrm{mm}^{2}\right)\end{array}$ & $\begin{array}{c}\mathrm{E}_{\mathrm{s}} \\
\left(\mathrm{N} / \mathrm{mm}^{2}\right)\end{array}$ \\
\hline D22 & 1187 & 1298 & $1.96 \mathrm{E}+5$ \\
\hline U6.4 & 1471 & 1506 & $2.05 \mathrm{E}+5$ \\
\hline U9.0 & 1405 & 1466 & $2.05 \mathrm{E}+5$ \\
\hline
\end{tabular}

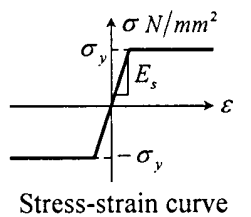

Fig. 3 Mechanical properties and analytical model for reinforcement

\section{2 実験における加力および測定方法}

加力装置を Fig. 4 に示寸。鉛直方向の加力は軸力比 0.15 で荷重一 定制御とした。水平方向の加力は変位制御による逆対称正負交番載 荷とし，柱の部材角， $R= \pm 1 / 400 ， \pm 1 / 200 ， \pm 1 / 100 ， \pm 1 / 67 ， \pm 1 / 50$ および $\pm 1 / 33$ で絽返し，耐力低下が認められた時点で終了した。

せん断ひび割れ幅の測定は，柱せい面にひび割れが発生してから 各サイクルピークにおいて横補強筋上に発生したひび割れ幅全てを 分解能 $0.01 \mathrm{~mm}$ のデジタルマイクロスコープを用いて測定した。Fig. 5 に示すようにひび割れ界面に詨し直交方向距離 $w$ をひび割れ幅と

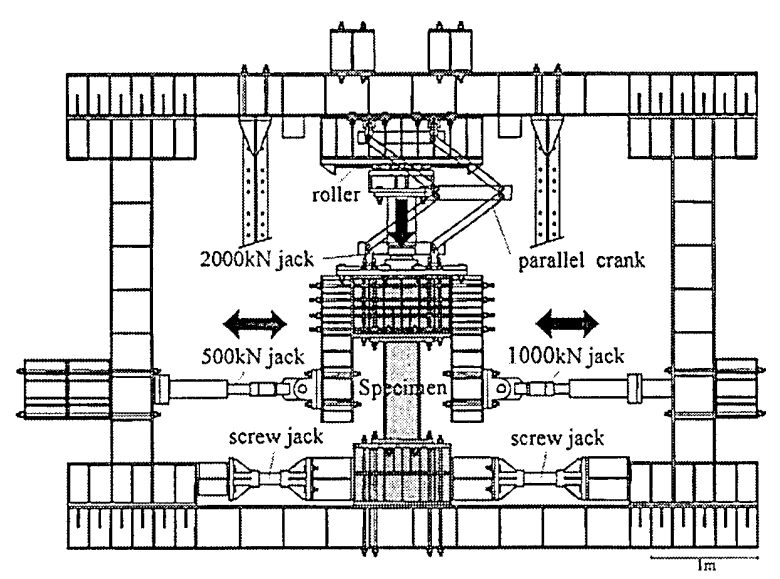

Fig. 4 Loading apparatus 
して計測し，横補強筋上の合計ひび割れ幅を求める際にはひび割れ

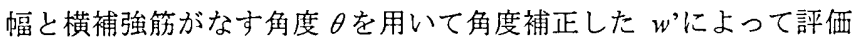
している。

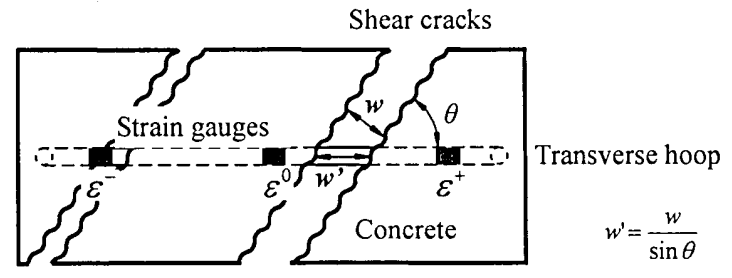

Fig. 5 Definition of crack width and designation of strain gauges

\section{3 解析におけるモデル化}

解析におけるモデル化, 境界条件, 使用した要素種別および加力 方法に関しては前報 ${ }^{3)}$ と同様である。コンクリートの圧縮応力上昇 部分には土木学会のコンクリート標準示方書 ${ }^{8)}$ の 2 次式を採用し, 最大耐力後の挙動は線形軟化すると仮定した (Fig. 2 参照)。コンク リートの圧縮破壊規準には Drucker-Prager 基準を採用し, 塑性ポテ ンシャルにも同じ関数を用いる関連流れ則を適用した ${ }^{9)}$ 。横補強 筋による横拘束を受けるコンクリートの Drucker-Prager 破填基準の 内部摩擦角は, 渡逢ら ${ }^{10}$ による横補強筋間隔とコンクリート強度を パラメータとした横拘束円柱コンクリートの圧縮実験より推定でき る ${ }^{3)}$ 。渡邀らは Fig. 6 に示すように，横補強筋間隔またはコンクリ 一ト強度が大きくなると, 横拘束に対する比例倸数（拘束効果）は 小さくなることを明らかにした。前報では，横補強筋間隔 $60 \mathrm{~mm}$, コンクリート強度 $\sigma_{\mathrm{B}}=50 \mathrm{~N} / \mathrm{mm}^{2}$ に対して, Richart の一様拘束圧に対 する比例係数 4.1 を渡邀ら ${ }^{100}$ の実験結果に基づいて 2.0 に低減し， 内部摩擦角を $20^{\circ}$ と推定した。したがって本報の Fc45 に対しては 前報と同様に内部摩擦角として $20^{\circ}$ を採用し, Fc90 に対しては横方 向の拘束効果がさらに低減することを考慮して, 内部摩擦角を $15^{\circ}$ とした(比例保数 1.7 相当)。この内部摩擦角を用いると Fc45 と Fc90 に対する Drucker- Prager 破壊基準は, 3 主応力 $\sigma_{1}, \sigma_{2}, \sigma_{3}$ によって(1) 式と(2)式のようになる ${ }^{3)}$ 。一方, 引張領域に対しては, Rankine の 最大引張応力基準 ${ }^{9}$ による tension-cutoff を採用し，引張軟化特性 にはバイリニアモデルを用いた（Fig. 3 参照）。ひび割れに関しては 分散ひび割れモデルを使用し，ひび割れ後のせん断剛性の低下は (3)式によるひび割れひずみの関数としている。

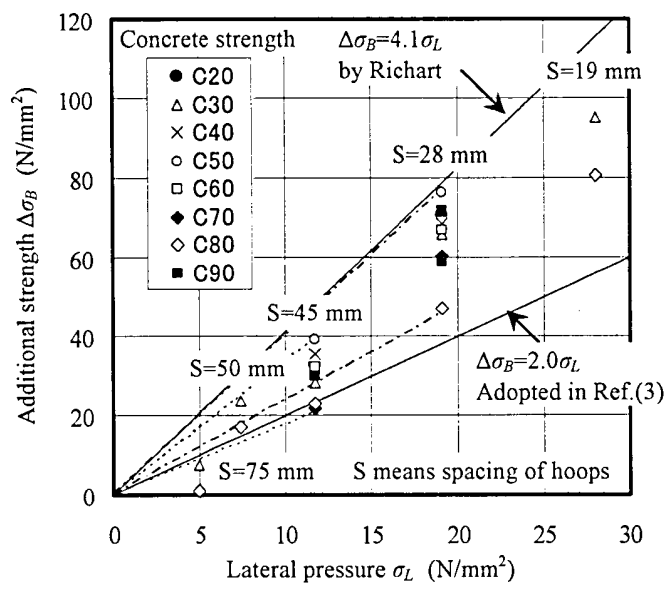

Fig. 6 Relations between lateral pressure and additional strength ${ }^{10)}$

$$
\begin{array}{rr}
f\left(I_{1}, J_{2}\right)=0.15 I_{1}+\sqrt{J_{2}}-19.3=0 & \text { for Fc45 } \\
f\left(I_{1}, J_{2}\right)=0.11 I_{1}+\sqrt{J_{2}}-42.1=0 & \text { for Fc90 } \\
I_{1}=\sigma_{1}+\sigma_{2}+\sigma_{3} & \\
J_{2}=\left[\left(\sigma_{1}-\sigma_{2}\right)^{2}+\left(\sigma_{2}-\sigma_{3}\right)^{2}+\left(\sigma_{3}-\sigma_{1}\right)^{2}\right] / 6 \\
\beta=\frac{1}{1+4447 \varepsilon_{\mathrm{n}}}
\end{array}
$$

\section{3. せん断酎カと横拘束効果の関係}

\section{1 せん断カー部材角関係}

Fig. 7 に実験結果と解析結果のせん断力 $Q$ 一部材角 $R$ 関係を比較 して示す。LPRC90-0.15 試験体は 1/33 サイクルの加力中に主筋の溶 接部が破断したため, 他の試験体の $Q-R$ 関係からほぼ最大耐力に近 いと判断し, 直前の-1/50 サイクルの荷重を最大耐力とした。実験の 破壊過程としては全試験体とも，はじめに曲げ引張領域に曲げひび 割れが現れ，斜め方向に伸展して曲げせん断ひび割れに成長し，そ の後, 部材対角方向にせん断ひび割れが発生した。最大耐力時には,

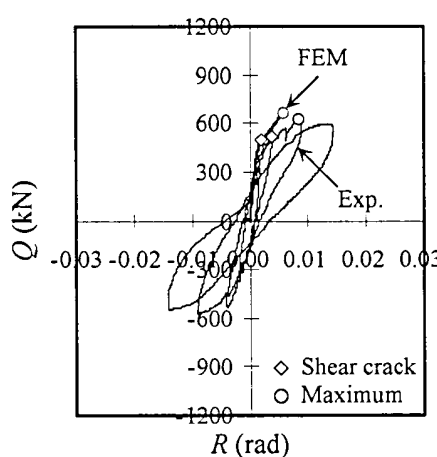

(1) RC45-0.30

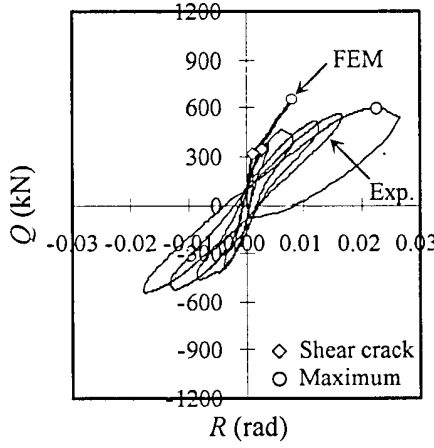

(3) RC45-0.15

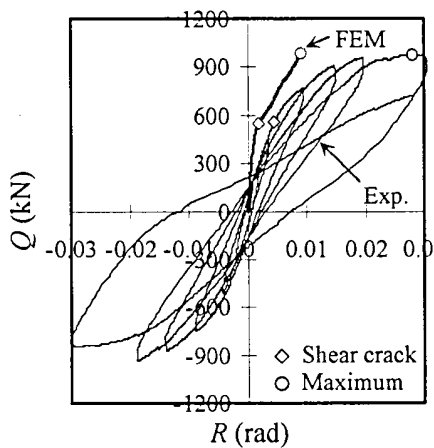

(5) RC90-0.15

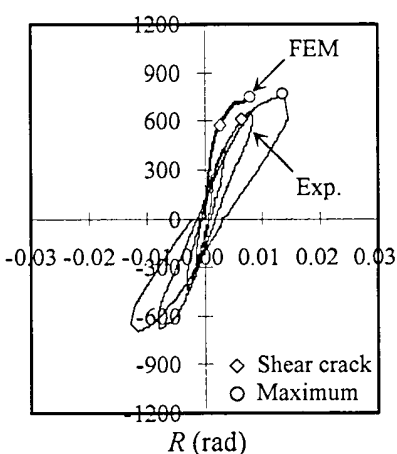

(2) LPRC45-0.3

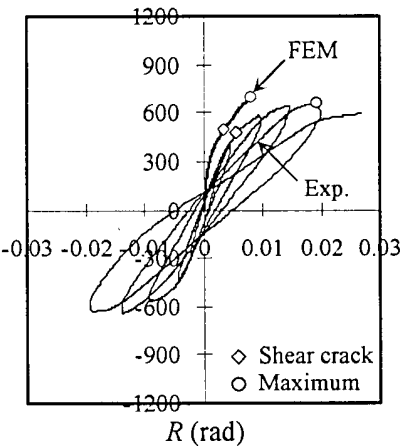

(4) LPRC45-0.15

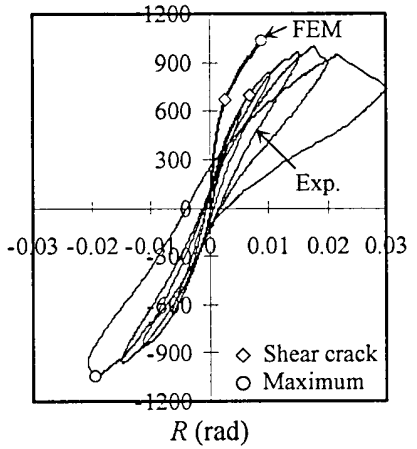

(6) LPRC90-0.15
Fig. 7 Comparisons between analytical and experimental Q-R 
部材端部の圧縮側（正面および側面）コンクリートに微細な鉛直ひ び割れが現れ，最終的にはこの圧縮側コンクリートの一部剥落を伴 う圧縮破壊となった。Fc45 シリーズの軸力比が 0.30 から 0.15 に減 少すると，せん断ひび割れ耐力が RC 試験体で 33\%，LPRC 試験体 で $22 \%$ 低下し，最大耐力は RC 試験体で $4 \%$, LPRC 試験体で $14 \%$ 低下するが，最大耐力時の部材角は両試験体とも倍增している。実 験結果と解析結果を比較すると，前報 ${ }^{2)} ゙$ 示したように，分散ひび 割れモデルを用いた解析では，ストレスロッキングや負側載荷時の ひび割れの影響により変形を過小評価している。特に軸力比が 0.15 の試験体はせん断ひび割れ発生後両者の相違は大きくなるが，耐力 はほぼ評価できている。なお実験・解析とも，全ての試験体の主筋 および横補強筋は加力終了まで降伏に至っていない。

\section{2 各種酎力と横拘束効果の関係}

Table 3 にせん断ひび割れ耐力と終局耐力に対して, 実験值 $(\exp Q)$ と解析值 $($ FEM $Q)$ を比較して示す。なお，解析におけるせん断ひび 割れ耐力は，横補強筋のひずみが急増する時点を，せん断終局耐力 は，6 章で述べるように収斂計算が不安定となる最終段階では，部 材端部の圧縮コンクリートが最大耐力後の軟化領域に入り，実験に おける破壊性状とも一致したことから，荷重が減少し始める直前の ステップとした。さらにせん断ひび割れ耐力として勒性保証式に横 方向プレストレスを考虑した文献 1)による計算值 $\left.{ }_{(c a l} Q_{s c}\right)$ を示して いるが，耐力をほぼ評価できている。また終局耐力として軸力を考 慮した修正荒川 mean 式による計算値 $\left({ }_{c a l} Q_{s u}\right)$ も参考に示している が，特に軸力の低い RC 試験体の耐力を安全側に評価している。

Table 3 Shear crack strength and ultimate shear strength

\begin{tabular}{|c|c|c|c|c|c|c|}
\hline $\begin{array}{c}\text { Test } \\
\text { Designation }\end{array}$ & $\begin{array}{c}\exp Q_{s c} \\
(\mathrm{kN})\end{array}$ & $\begin{array}{c}\exp Q_{s u} \\
(\mathrm{kN})\end{array}$ & $\begin{array}{c}F E M Q_{s c} \\
(\mathrm{kN})\end{array}$ & $\begin{array}{c}F E M Q_{s u} \\
(\mathrm{kN})\end{array}$ & $\begin{array}{c}c a l \\
(\mathrm{kN})\end{array}$ & $\begin{array}{c}c a\left(Q_{s u}\right. \\
(\mathrm{kN})\end{array}$ \\
\hline RC45-0.15 & 343 & 595 & 316 & 646 & 339 & 484 \\
\hline LPRC45-0.15 & 475 & 658 & 498 & 699 & 450 & - \\
\hline RC90-0.15 & 562 & 973 & 551 & 983 & 564 & 820 \\
\hline LPRC90-0.15 & 780 & 1048 & 669 & 1027 & 774 & - \\
\hline RC45-0.30 & 515 & 617 & 495 & 655 & 496 & 591 \\
\hline LPRC45-0.30 & 611 & 762 & 577 & 747 & 606 & - \\
\hline
\end{tabular}

$\exp Q_{s c}=$ shear crack strength by experiment, $\exp Q_{s w}=$ ultimate shear strength by experiment ${ }_{F E M} Q_{s c}=$ shear crack strength by FEM, $F_{E M} Q_{s u}=$ ultimate shear strength by FEM

${ }_{c a r} Q_{s c}=$ shear crack strength by ref.(1), $c_{c a l} Q_{s u}=$ ultimate shear strength by modified Arakawa

実験より得られたせん断ひび割れ耐力 ${ }_{\text {exp }} Q_{s c}$ を全断面積で除した 平均せん断ひび割れ応力 $\exp _{s c}\left(=_{\exp } Q_{s c} b D\right)$ と横方向プレストレス $\sigma_{L}$ の関係，およびせん断終局耐力の実験值を全断面積で除した平均最 大せん断応力 $\exp _{s u}$ と横方向プレストレス $\sigma_{L}$ の関係を Fig. 8 に示す。 なお，コンクリート強度 $\sigma_{B}$ に対する横方向プレストレス $\sigma_{L}$ の比 (= $\left.\sigma_{L} / \sigma_{B}\right)$ によって検討するため, 横軸は $\sigma_{L} / \sigma_{B}$ としている。コン クリート強度に比例した横方向プレストレスを導入することによっ て，せん断ひび割れ耐力，終局耐力ともほぼ同じ割合で増加してい る。せん断ひび割れ耐力に関しては，軸力比の大きな RC 試験体は ひび割れ強度が高く，横方向プレストレスを導入してもその効果は 小さい。一方，せん断終局耐力に関しては，軸力比が小さくなると 横方向プレストレスの効果も小さくなる。これは内部コンクリート の拘束状態などに起因すると考えられ，6 章の解析で考察する。続
いて，Fig. 9 にせん断ひび割れ耐力とせん断終局耐力について実験 值と解析值の比較を示した。実験と解析は全体的に良い対応を示し ており，三次元有限要素解析によって，せん断ひび割れ耐力および 終局耐力をほぼ評価することができている。

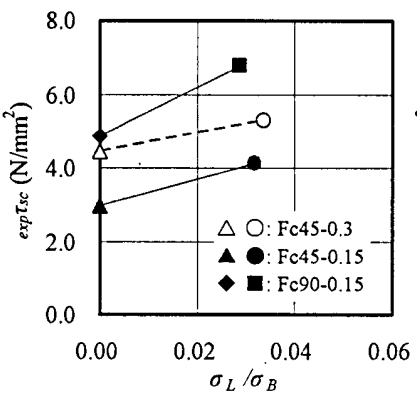

(1) Shear crack strength

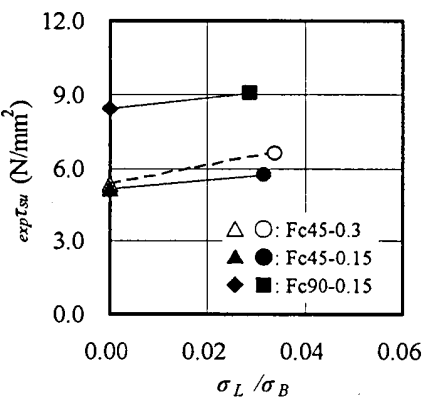

(2) Ultimate shear strength
Fig. 8 Increase of strength with increasing lateral prestress $\sigma_{L}$

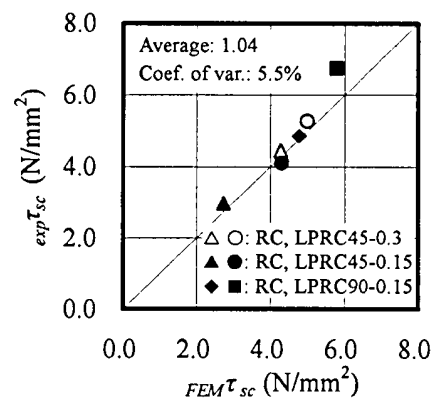

(1) Shear crack strength

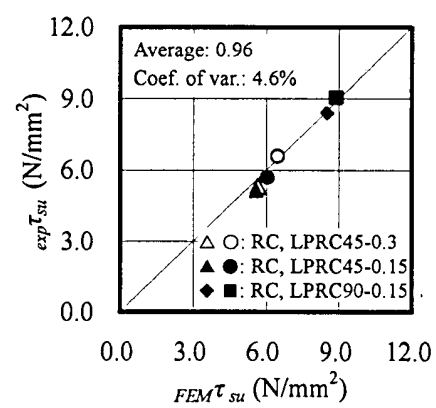

(2) Ultimate shear strength
Fig. 9 Comparison of strength from experiment and FEM analysis

\section{4. せん断ひび割れおよび横補強筋の挙動 \\ 4.1 せん断ひび割れ性状}

Fig. 10 に各試験体の最大耐力時におけるひび割れ性状を示す。同 図には最大ひび割れ幅を検出した箇所をロで示し，さらにそのひび 割れを含む角度を記している。なお，ここでの最大せん断ひび割れ 幅とは，横補強筋上だけではなく，試験体のせい面で計測されたも ののうち最も大きなせん断ひび割れ幅とした。主筋に沿って付着ひ び割れも発生しているが，文献 4)の付着割裂防止筋を取り外した試 験体と異なり，加力終了までそのひび割れ幅が拡大することはなか った。Fig. 11 に部材に生じたせん断ひび割れ幅の履歷をせん断力 $Q$ と最大せん断ひび割れ幅 exp $_{\text {max }}$ （Fig. 10 の）の関係で示す。グラ フはせん断ひび割れ耐力（ひび割れ幅 $0 \mathrm{~mm}$ ）から始まり，せん断

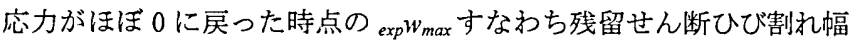
までを示している。Fc45 シリーズでは, 軸力比の低下によりひび割 れ幅は増大し，特に RC 試験体では最大耐力時で $1 \mathrm{~mm}$ を超えてい る。一方, LPRC 試験体では最大耐力時のせん断ひび割れ幅は RC 試験体の半分以下であり，残留せん断ひび割れ幅は制御目標值とし て一般に用いられている $0.2 \mathrm{~mm}^{11)}$ を下回っている。Fc90 シリーズの 横補强筋比は Fc45 シリーズの 2 倍強であるため, RC 試験体におい ても最大耐力時のひび割れ幅が小さく, Fc45 シリーズほど横方向プ レストレスの効果が顕著ではない。またせん断ひび割れが卓越する 横補強筋+4〜-4 の各ひび割れ角度 $\theta$ (Fig. 5 参照) の平均值を Table-4 に示す。Fig. 10 と Table-4 より支配的なひび割れ角度と平均 
ひび割れ角度は, 軸力比の低下または横方向プレストレスの導入に よって小さくなる傾向を示している。またこれらのひび割れ角度は， コンクリートの引張破壊基準に Rankine の最大主応力説を用いると, 軸力による垂直応力，プレストレスによる横方向垂直応力およびせ ん断ひび割れ強度に相当するせん断応力が作用する要素の Mohr の

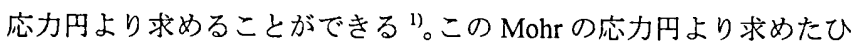
び割れ角度も Table-4に記載しているが，実験結果とほぼ対応して おり，最大主応力説の妥当性を示している。せん断補強筋量の多い Fc90 試験体の場合, ひび割れ角度の実験值が小さいことから，ポア ソン効果により初期導入プレストレス以上の横拘束がひび割れ強度 時に作用していた可能性がある。

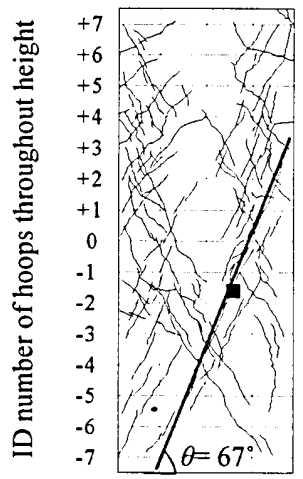

${ }_{\text {Exp }} Q_{\max }=617 \mathrm{kN}$

(1) RC45-0.30

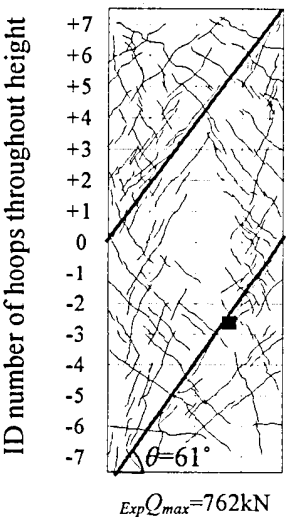

$E_{x p} Q_{\max }=762 \mathrm{kN}$

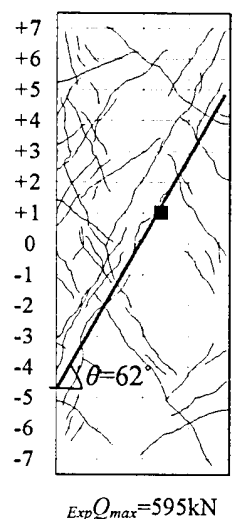

(3) RC45-0.15

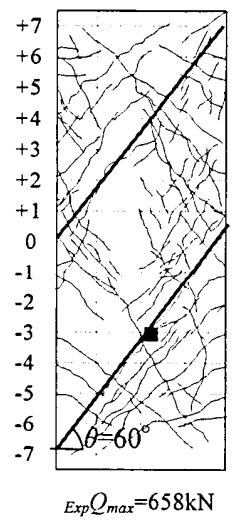

(4) LPRC45-0.15

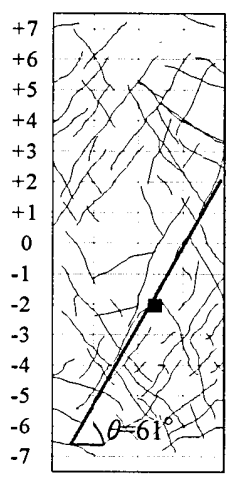

$E_{x p} Q_{\max }=973 \mathrm{kN}$

(5) RC90-0.15

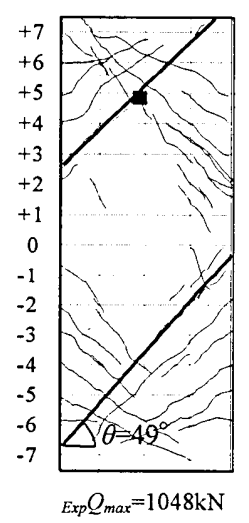

(6) LPRC90-0.15
Fig. 10 Crack patterns at maximum shear loads

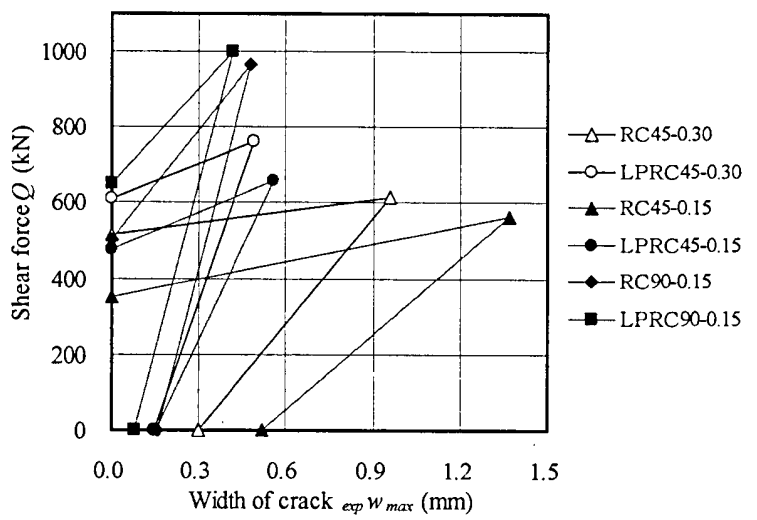

Fig. 11 Relations between shear force and maximum crack width
Table 4 Averaged angle of crack from experiment and Mohr's circle

\begin{tabular}{|c|c|c|c|c|c|c|}
\hline $\begin{array}{c}\text { Test } \\
\text { Designation }\end{array}$ & $\begin{array}{c}\text { RC45- } \\
0.30\end{array}$ & $\begin{array}{c}\text { LRC45- } \\
0.30\end{array}$ & $\begin{array}{c}\text { RC45- } \\
0.15\end{array}$ & $\begin{array}{c}\text { LPRC45- } \\
0.15\end{array}$ & $\begin{array}{c}\text { RC90- } \\
0.15\end{array}$ & $\begin{array}{c}\text { LPRC90- } \\
0.15\end{array}$ \\
\hline Experiment & $69^{\circ}$ & $62^{\circ}$ & $64^{\circ}$ & $61^{\circ}$ & $65^{\circ}$ & $55^{\circ}$ \\
\hline Mohr's circle & $69^{\circ}$ & $64^{\circ}$ & $63^{\circ}$ & $57^{\circ}$ & $67^{\circ}$ & $59^{\circ}$ \\
\hline
\end{tabular}

\section{2 横補強筋ひずみとひび割れ幅の関係}

文献 3)では，コンクリートのひずみを無視し，横補強筋ひずみを 積分することによって算出したひび割れ幅と，加力中マイクロスコ ープによって計測した補強筋上の合計ひび割れ幅との間に高い相関 が存在することを示した。Fig. 12 は，横補強筋に貼付したひずみか ら算出したひび割れ幅 $\left(\triangle \mathrm{F}^{-}\right)$と，対応する横補強筋上で計測した マイクロスコープによるひび割れ幅の合計值（口印）を各横補強筋 レベル毎に比較して示している。ただし，比較した時点の部材角は， 軸力比 0.30 シリーズでは最大耐力時の部材角であるが, 軸力比 0.15 シリーズの RC 試験体では最大耐力時の部材角が $1 / 33$ に達し，その 時点ではかぶりコンクリートの浮きなどによりひび割れ幅の計測を 行っていない。そこでその前サイクルの加力でほぼ最大耐力に達し ているとして (Fig. 7 参照), 部材角 1/50 の時点で比較している。同 図にはまた, FEM 解析による横補強筋の伸び量から評価したひび割 れ幅（○印）も合わせて示している。マイクロスコープで実測した
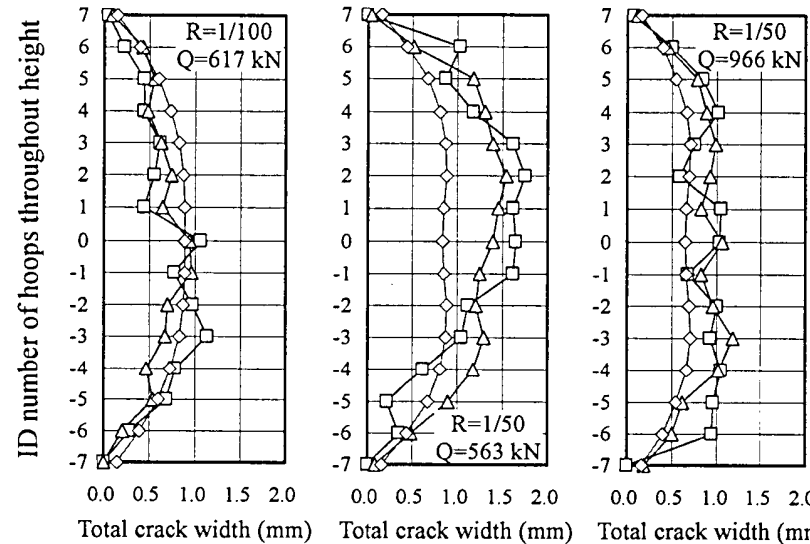
total crack width $(\mathrm{mm})$ Total crack width $(\mathrm{mm})$ Total crack width $(\mathrm{mm})$ (1) RC45-0.30

(3) RC45-0.15

(5) RC90-0.15
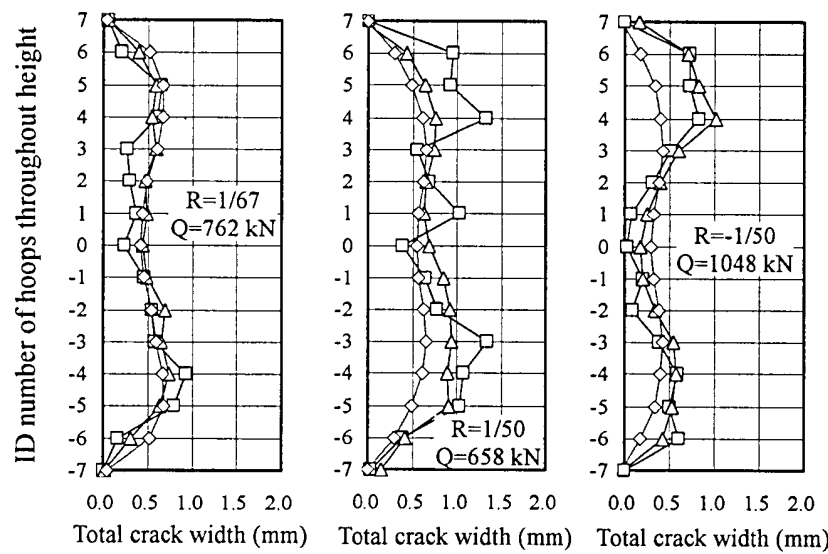

(2) LPRC45-0.30

(4) LPRC45-0.15

(6) LPRC90-0.15

Fig. 12 Total crack width obtained from microscope, strain of shear reinforcement and FEM analysis 
ひび割れ幅は表面の値であり，横補強筋のひずみにより評価した横 補強筋位置のひび割れ幅と直接比較することはできないが，本試験 体ではかぶり厚さが $9 \mathrm{~mm}$ と小さいため，全体的に両者のひび割れ 幅は同様な挙動を示している。FEM 解析によるひび割れ幅に関して は, 軸力比 0.30 シリーズでは実験值と整合性が良いが, 軸力比 0.15 シリーズでは実験值を過小評価する傾向がある。これは横補強筋を 完全付着としてモデル化しているため，Fig. 7 に示すように部材角 が大きくなる軸力比 0.15 シリーズでは, せん断剛性を過大に評価し たことに起因していると思われる。Fig.12 の下段に示す LPRC 試験 体は上段の RC 試験体と比較すると，最大耐力時においても横方向 プレストレスによりせん断ひび割れ幅を抑制しており，また部材中 央より端部のひび割れが成長しているが，これらのせん断ひび割れ 挙動の特徴に関しては，三者のひび割れ評洒法はいずれも良く捉え ている。Fc45 シリーズで比較すると, 軸力比が小さくなるとせん断 耐力は低下するがひび割れ幅は増大し，Fc90 シリーズでは横補強筋 量を 2 倍強としているため, せん断耐力は增加しているがひび割れ 幅は減少している。

\section{5. 解析による横補強筋经の検討}

2 章で述べたように, Fc90 試験体に対して横補強筋に U6.4 を使用 すると,コンクリート強度に比例したプレテンションを導入する際, 破断する恐れがあるため，U9.0 を使用した。しかしながら 3 章と 4 章で示したように, 横補強筋量の相違は $Q-R$ 関係やせん断ひび割れ 性状に大きな影響を与えている。そこで本章では，Fc90 試験体に U6.4 を使用した場合の三次元有限要素解析を行い, せん断挙動に及 ぼす横補強筋量の影響について検討する。

Fig.13 に RC90-0.15 試験体と LPRC90-0.15 試験体に横補強筋とし て U6.4 を使用した場合と U9.0を使用した場合の $Q-R$ を比較して示 す。 $\mathrm{RC}$ 試験体では横補強筋量が減少するとせん断ひび割れ後の剛 性も低下し, 最大耐力は $6 \%$ 程度低下している。横方向プレストレ ス導入量を同一とした LPRC 試験体では，横補強筋量に関わらずせ ん断ひび割れ後の剛性はほぼ同じである。ただしU6.4の補強笳はせ ん断力 $943 \mathrm{kN}$ で補強筋の降伏が始まると同時に, 収束計算が不安定 となったため, 解析を終了している。

Fig.14 はせん断ひび割れ幅を解析によって評価し，横補強筋量に よるひび割れ幅の相違を比較している。RC 試験体は横補強筋量を U9.0 から U6.4に減少すると，最大耐力が $63 \mathrm{kN}$ 低下するにも関わ らず，ひび割れ幅は約 5 割増加している。一方 LPRC 試験体は，同 一のプレストレス量を導入したため，同一せん断荷重時で比較する

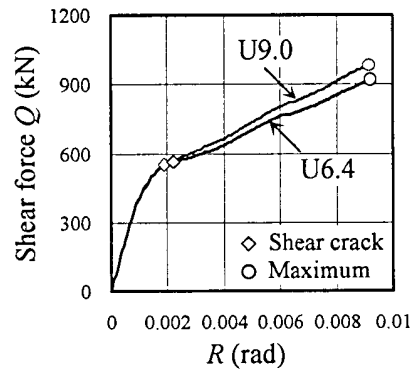

(1) RC90-0.15

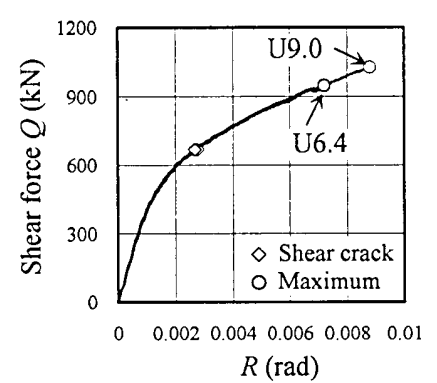

(2) LPRC90-0.15
Fig. 13 Q-R curves with different diameter of shear reinforcement
と, 横補強筋量の減 少によりせん断ひび 割れ幅は増加するが， その差は僅かであり, せん断ひび割れ幅を よく制御していると いえる。この RC 試 験体と LPRC 試験体 のひび割れ性状の相 違がせん断ひび割れ 後のFig.13にみられ る $Q \cdot R$ 関係に影響を 及ぼしていると思わ れる。

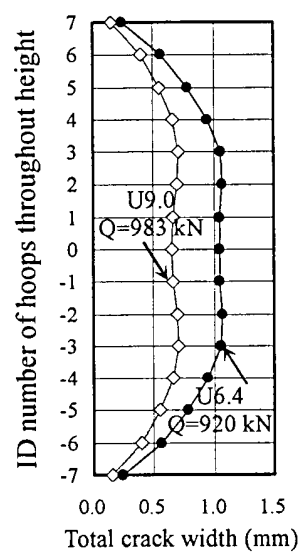

(1) RC90-0.15

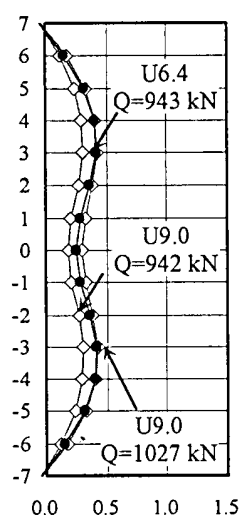

Total crack width (mm)
Fig. 14 Total crack width with shear reinforcement $\mathrm{U} 9.0$ and $\mathrm{U} 6.4$

\section{6. 解析による内部応力状態の険討}

本章では，横方向プレストレスが RC 柱のせん断挙動に及ぼす効 果を, 内部コンクリートの三軸応力状態に基づいて考察する。Fig. 15 に試験体中央面における最大荷重時の最小主応力分布を示す。文献 (3)では，ひび割れが分散し一体性を保持した LPRC 試験体は RC 試 験体より圧縮ストラット幅が広くなり，せん断耐力の増加の要因と なることを示した（Fig.15 の RC45-0.30 と LPRC45-0.30）。軸力比を 0.15 とした今回の試験体では, 軸力比 0.30 の試験体ほど横方向プレ ストレスの影響が最小主応力分布に顕著に現れていない（Fig.15 の RC45-0.15 と LPRC45-0.15)。このことから軸力比が小さくなると， せん断耐力に及ぼす横方向プレストレスの効果が減少したと考えら れる。また横補強筋量が多いRC90-0.15(U9.0)では，ひび割れが分散 し，その幅を抑制したため（Fig.10 と Fig.12 参照），比較的広い圧 縮ストラット幅となり，横方向プレストレスを導入するとさらに搪 がるが，軸力比 0.30 の場合に比べるとその差は小さい。さらに横補 強筋量が少ない LPRC90-0.15(U6.4)では，横補強筋の降伏により RC 試験体と同程度のせん断耐力となっており，最小主応力分布の形状 は多少大きくなるがその絶対値は小さくなっている。

Fig. 16 に最大せん断荷重時における試験体表面の損傷度を示す。 なお,ここで用いる損傷度とは, Fig. 17 に示寸応力の不変量 $\xi-r$ 平 面上における偏差応力成分 $r$ によって，どの程度圧縮破壊曲面に近 いかを示す圧縮破壊危険度であり，静水圧 $\xi$ 軸上で 0 , 破壊曲面上 で 1 と定義している。文献(3)で示したのと同様，同じせん断荷重で 比較すると LPRC 試験体は RC 試験体より損傷が分散し，その程度 も低く抑えられている。部材端部の圧縮領域における白点を有する 赤色は, コンクリートの応力状態が最大耐力後の軟化領域に達して いる箇所であり，実験において観察された最大耐力近傍における端 部圧壊と対応している。文献(3)では，RC 試験体は，軟化領域が局 所化されるのに対し，LPRC 試験体の軟化領域はより広範囲に形成 され，Fig.15 の最小主応力分布の拡がりとも関連させて，横方向プ レストレスによるせん断耐力上昇を説明した（Fig.16の RC45-0.30 と LPRC45-0.30)。ところが同じ横方向プレストレス導入量であって も軸力比が小さくなると, 最小主応力分布と同様に, この軟化領域 の拡がりは小さくなり（Fig.16の RC45-0.15 と LPRC45-0.15), 横方 向プレストレスの効果が低下している。また, Fc45 (上段) と Fc90(下 


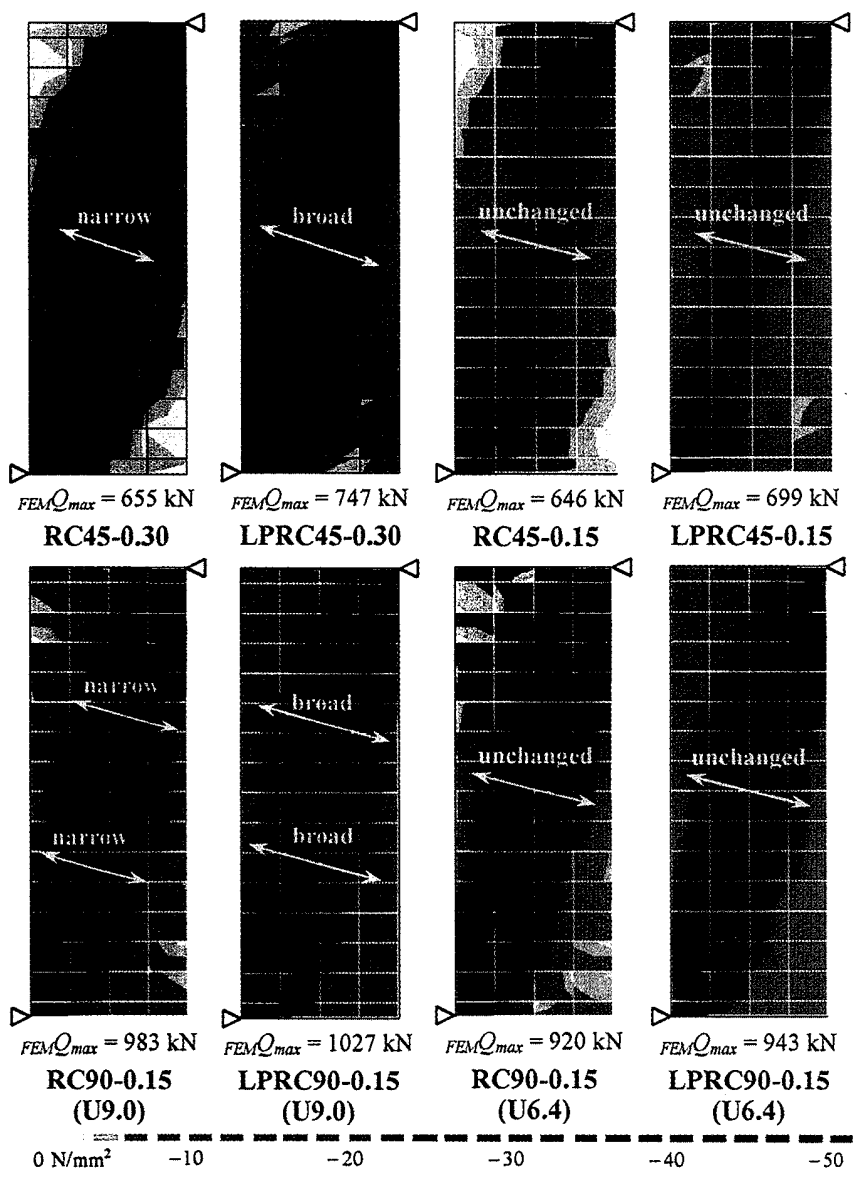

Fig. 15 Compression strut based on minor principal stress at $Q_{\max }$
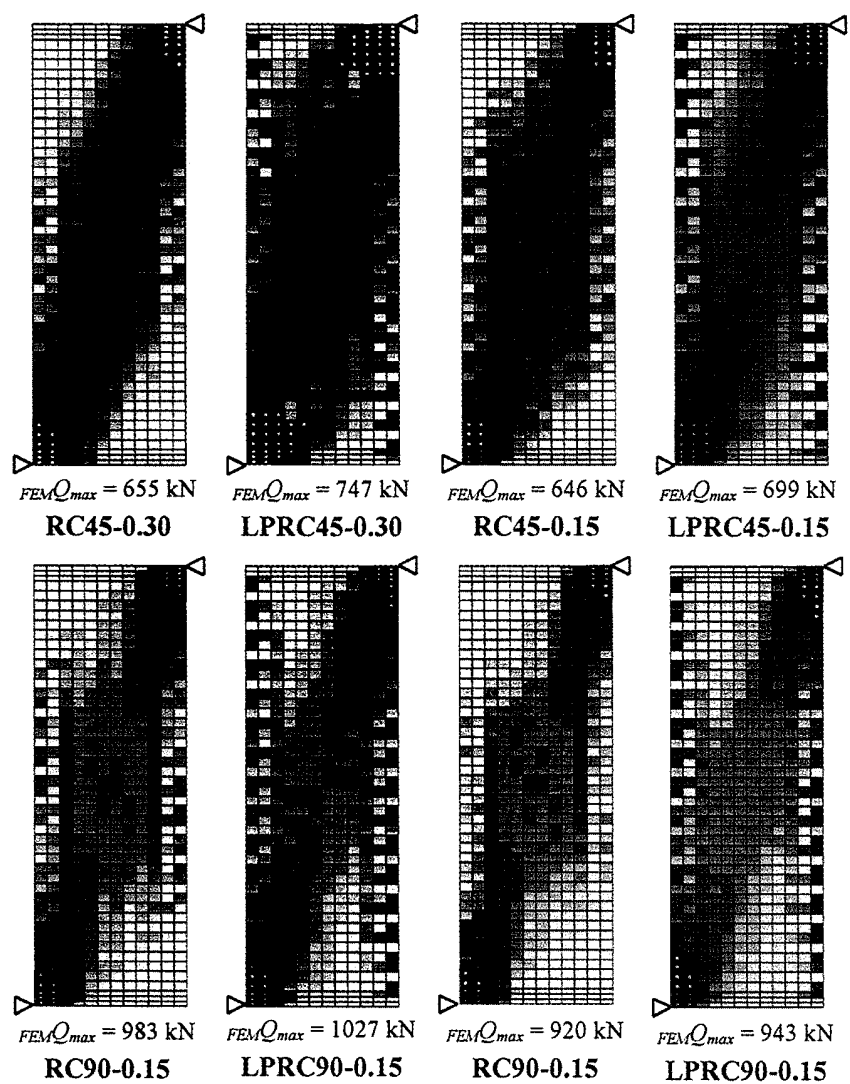

(U9.0)
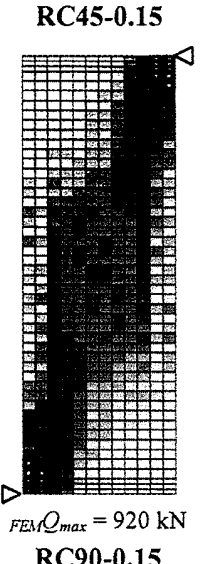

(U6.4)

\section{LPRC45-0.15}

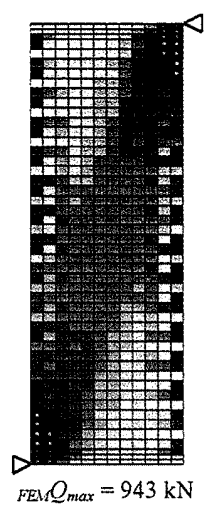

LPRC90-0.15

(U6.4)

$0.0 \sim 0.1 \sim 0.2 \sim 0.3 \sim 0.4 \sim 0.5 \sim 0.6 \sim 0.7 \sim 0.8 \sim 0.9 \sim 1.0$

Fig. 16 Comparison of damage in compression zone at $Q_{\max }$

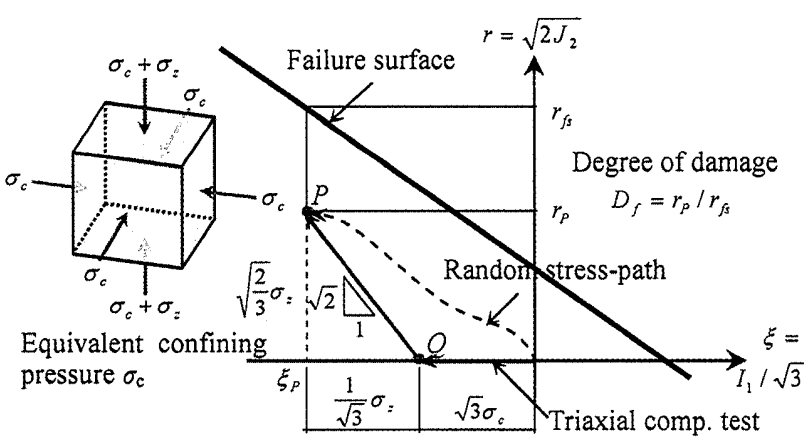

Fig. 17 The degree of damage and equivalent confining pressure for triaxial state of stress in meridian plane of Drucker-Prager criterion

段)の軟化領域を比較すると，Fc90 のほうがこの領域が端部に限ら れて局所化しており，横補強筋量に関わらず横方向プレストレスの 効果は小さくなっている。さらに両者を全体で比較すると，Fc90の ほうが Fc45 より損傷度は小さくなっている。このことから高強度コ ンクリートは全体的には健全であっても，一部の局所的な破壊によ り耐力が決定する，いわゆる寸法効果に敏感な材料であることが推 察できる。したがって高強度コンクリートを使用する場合，局所的 な破壊を遅らせるために，鉄筋量を増やし，ひび割れを分散させる ことが必要である。

横方向プレストレスによるコアコンクリートの拘束効果を比較す るため，最大耐力時における等価拘束圧を Fig. 18 に示す。等価拘束 圧は Fig. 17 に示す応力の不変量 上の一般応力状態を側圧一定の三軸圧縮実験経路上の応力状態に換 算した場合の側圧と定義し，側圧を 1 軸圧縮強度で除して基準化し ている。等価拘束圧は 3 主応力がほぼ等しい静水圧状態を保持して 大きくなると増加するが，静水圧成分 $゙$ が同じであっても 3 主応力 の差が大きくなると，すなわち偏差応力成分 $r$ が増加すると等価拘 束圧は減少する。文献(3)の LPRC 試験体では，軸力導入時から高い 拘束効果が得られ, 最大耐力時まで $\mathrm{RC}$ 試験体より広範囲に拘束効 果が現れていることを示した（Fig.18の RC45-0.30 と LPRC45-0.30）。 Fc45 シリーズの軸力比の影響を見ると，RC45-0.15 試験体は局所的 に 0.30 の試験体より等価拘束圧が大きくなり，両者の耐力にも大き な相違は見られない。一方 LPRC45-0.15 試験体は，0.30の試験体よ り等価拘束圧が小さく，拘束効果が低下している。また補強筋量の 多いFC90-U9.0 試験体は, RC 試験体においても比較的高い等価拘束 圧を示しており，プレストレス導入による拘束効果の影響は小さく なっている。また RC-90-0.15-U6.4 試験体は U9.0 の試験体に比べて 等価拘束圧の高い領域は局所化するが，プレストレスを導入するこ とによりその領域が拡大する傾向が見られる。

\section{7. まとめ}

横方向プレストレスによる能動的拘束に及ぼすコンクリート強度 および軸力比の影響を検討するため, 軸力比 0.15 でFC45 と Fc90の コンクリート柱の曲げせん断実験および三次元有限要素解析を行い, 本研究範囲内で以下の知見が得られた。

1）軸力比が小さくなると, 横方向プレストレスによる能動的拘束 効果は低下する。その要因を最小主応力分布, 圧縮領域の損傷 度，等価拘束圧を用いて明らかにした。 

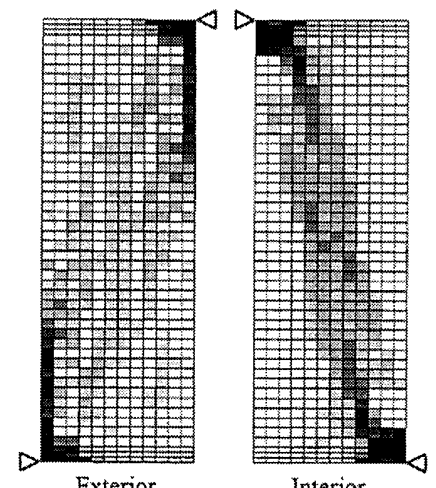

(1) RC45-0.30 $(Q=655 \mathrm{kN})$

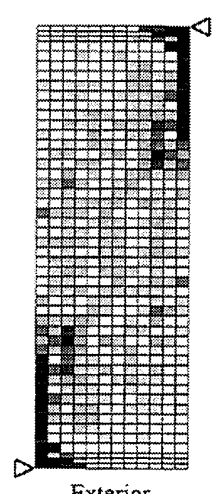

Exterior

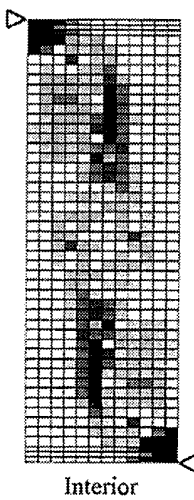

(3) $\mathrm{RC45-0.15}(Q=646 \mathrm{kN})$
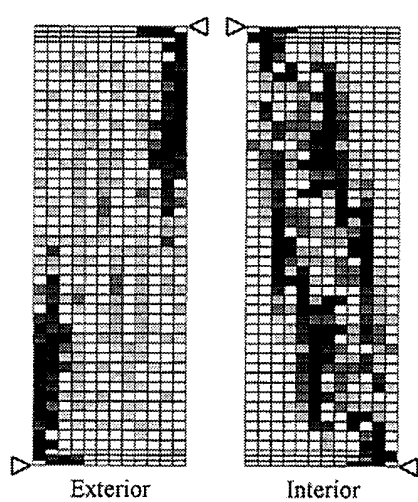

(5) $\mathrm{RC} 90-0.15-\mathrm{U} 9.0(Q=983 \mathrm{kN})$

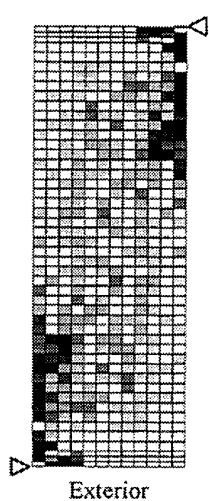

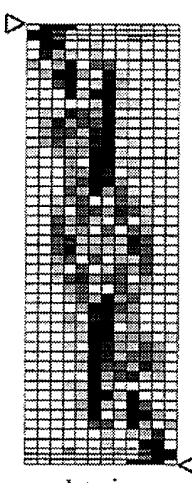

Interior

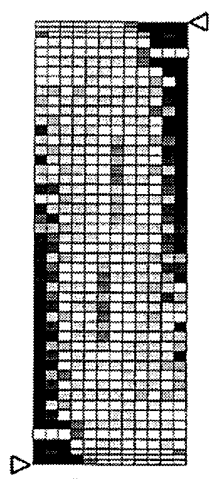

Exterior

(2) $\mathrm{CPRC} 45-0$

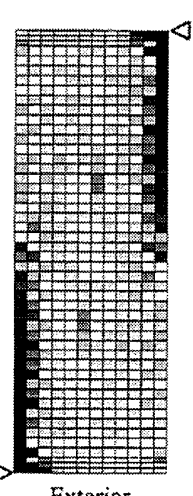

Exterior (4) LPRC45-0.15 $(Q=699 \mathrm{kN})$
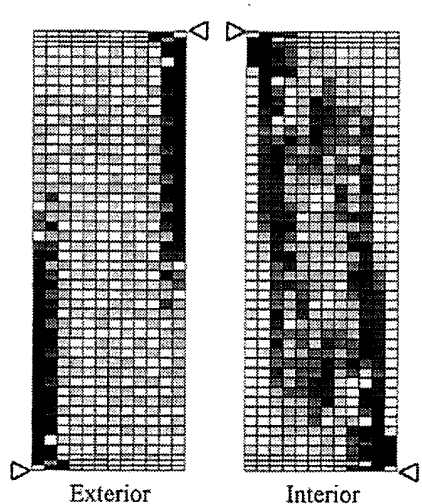

(6) LPRC90-0.15-U9.0 $(Q=1027 \mathrm{kN})$

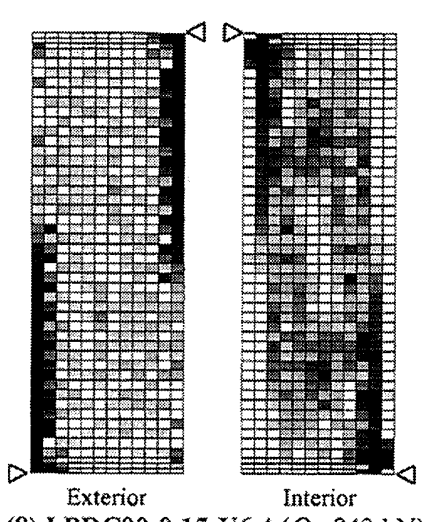

2）コンクリート強度に比例した横方向プレストレス量を与える ことにより, 高強度コンクリートの場合もほぼ同等な拘束効果 が得られる。

3）横補強筋量が多い場合, ひび割れが分散するため, 横方向プレ ストレスによる拘束効果は低下する。

4）横補強筋量が少ない場合, 横方向プレストレスを導入しなけれ ばせん断ひび割れ後の剛性が低下するが, 横補強筋量の多い試 験体と同量のプレストレスを導入すると, 補強筋が降伏しない 限りひび割れ後の剛性低下はかなり改善できる。

5）高強度コンクリートは一部の局所的な破壊により耐力が決定 する傾向があり，寸法効果に敏感な材料である。

\section{謝辞}

高周波熱鍊（株）には鉄筋をご提供いただきました。また，本研 究の一部は, 平成 $17 \cdot 18$ 年度日本学術振興会科学研究費補助金 (基 盤研究 C(2)・課題番号 : 17560499 - 研究代表者 : 篠原保二) により ました。付記して謝意を表します。

\section{参考文献}

1) 渡部洋, 香取慶一, 簙原保二, 林静雄 : 横方向プレストレスによる鉄筋 コンクリート柱のせん断ひび割れ制御と終局耐力の評価, 日本建築学会 構造系論文集, No.557, pp.109〜116, 2004.3

2) 策原保二, 宮野覚也, 渡部洋, 林静雄: 横方向プレストレス RC 柱の能 動的拘束効果と破壊メカニズムに関する解析的研究, 日本建築学会構造 系論文集，No.558，pp.115 121，2004.4

3）簠原保二, 宮野覚也, 渡部洋: 横方向プレストレスを導入した鉄筋コン クリート柱の能動的拘束効果とせん断ひび割れ性状, 日本建築学会構造 系論文集, No.587, pp.147〜153，2005.1

4) 簙原保二, 殿原 啓伸, 大家史, 渡部洋: 横方向プレストレスを導入し た RC 柱の付着性状に及ぼす能動的拘束の影響, 日本建築学会構造系論 文集，No.608，pp119 126，2006.10

5) 篠原保二, 朴世万, 大家史, 渡部洋 : 横方向プレストレスを導入した高 強度コンクリート柱のせん断挙動に関する研究（その1）（その 2)，日 本建築学会大会学術講演梗概集 C, pp.351 354, 2006.9

6) 渡部洋, 朴世万, 篠原保二, 林静雄: 横方向プレストレスを導入した高 強度コンクリート柱のせん断挙動に関する研究, コンクリート工学年次 論文集，Vol.28，No.2，pp.139〜144，2006.7

7) 日本建築学会 : 鉄筋コンクリート造建物の勒性保証型耐震設計指針・同 解説, 1999.8

8）士木学会：コンクリート標準示方書［構造性能照查編］，2002

9) Chen, W. F. : Plasticity in Reinforced Concrete, McGraw-Hill Book Company, 1982

10) 高森直樹, Benny Benni Assa, 西山峰広, 渡邊史夫 : 横拘束コンクリー トの忘力度一ひずみ度関倸定式化に関する基礎的実験研究, コンクリー 卜工学年次論文集, Vol.18，No. 2, pp.395-400，1996.7

11）例えば，日本建築学会：プレストレスト鉄筋コンクリート（而種 PC） 構造設計・施工指針・同解説, 1986

(2006年 9 月 5 日原稿受理, 2006 年11月 24 日採用決定)

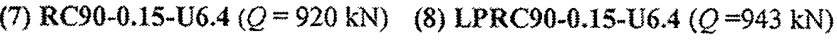

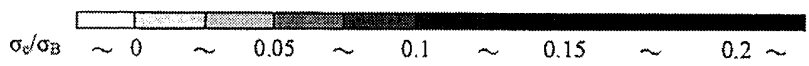

Fig. 18 Equivalent confining pressure at maximum shear load 